\title{
LET'S GO BANANAS! GREEN BANANAS AND THEIR HEALTH BENEFITS
}

\author{
Vasso Apostolopoulos ${ }^{1,{ }^{*}}$, Juliana Antonipillai ${ }^{1}$, Kathy Tangalakis ${ }^{1}$, John F Ashton ${ }^{2}$, Lily Stojanovska ${ }^{1}$ \\ ${ }^{1}$ Centre for Chronic Disease, College of Health and Biomedicine, Victoria University, St Albans Campus, \\ Melbourne, VIC Australia \\ ${ }^{2}$ Sanitarium Development and Innovation, Cooranbong, NSW, Australia
}

Corresponding author: Vasso Apostolopoulos, Centre for Chronic Disease, College of Health and Biomedicine, Werribee Campus, Hoppers Lane, Werribee, VIC 3030, T: +613 99192025, Fax: +613 99192465,

Email: vasso.apostolopoulos@vu.edu.au

\begin{abstract}
Bananas have enormous health benefits as a food for both animals and humans. They have been used as a complimentary medicine to treat pathological conditions since ancient times. Recently, there has been increased interest in the scientific validity of the beneficial effects of bananas in alleviating and treating disease conditions including, ulcers, infections, diabetes, diarrhea, colitis and blood pressure. Herein, we write on the potential therapeutic and functional benefits of certain species of bananas when consumed green as well as considering the properties of extracts from the non-fruit parts of the plant. We conclude that green bananas appear to deliver an array of health and therapeutic benefits
\end{abstract}

Key words: Banana, Green banana, Health, Musa paradisiacal, Nutrition

\section{INTRODUCTION}

Banana plants and fruits have been known since ancient times as a source of biologically active products. In recent years, there has been an upsurge in interest for their use by the pharmaceutical industry and in functional foods. Bananas and in particular green bananas are reported to have medicinal benefits, although there is limited scientific evidence. Many of the large number of banana species available are consumed when their ripened fruits are sweet. However a few species, such as "Monthan" (Musa paradisiacal), are less sweet to taste and people consume them when unripe or green. We present a review of the scientific literature relating to the use of unripe green bananas and their potential therapeutic benefits and suggest that there is a need to investigate the use of green banana foods as alternative compli- mentary treatment options available for alleviating a number of conditions such as diabetics, kidney stones, hypercholesterolemia and infection.

\section{METHODOLOGY}

Herein, we present health benefits of green bananas, using PubMed searches with the following key terms: green banana (or Musa paradisiacal) AND health, green banana (or Musa paradisiacal) AND disease, green banana (or Musa paradisiacal) AND diarrhea, green banana (or Musa paradisiacal) AND inflammation, green banana (or Musa paradisiacal) AND virus, green banana (or Musa paradisiacal) AND bacterial infection, green banana (or Musa paradisiacal) AND diabetes, green banana (or Musa paradisiacal) AND cholestrol, green banana (or Musa paradisiacal) AND infection. In particular, publications from 2006-2016 are mostly cited. 


\section{Green Bananas and Health Benefits}

Green bananas in general are incredibly nutritious and can serve as a good source of fiber [1], resistant starch [2], vitamin A [3], vitamin B6 [4, 5], vitamin $C$ [1] and potassium [1]. Banana flour made from dehydrated or naturally dried green banana (including monthan species) [1] are used as substitute flour in many dishes including gluten free meals [6]. Flour prepared with the banana skin (unpeeled), has a higher nutritional value with higher content of minerals, dietary fibers, total phenolics and higher anti-oxidant activity than peeled [7]. However, there are significant anti-fungal compounds in banana skins that need to be considered [8]. The human health implications both positive and negative may need to be more closely evaluated when unpeeled bananas are used in foods.

Diarrhea is a common gastrointestinal problem in children. A green banana diet has been shown in some studies to control diarrhea activity and infants with a history of diarrhea have been successfully treated following consumption of cooked green bananas [9-12]. In one study, cooked green bananas given to 73 children aged 6-60 months who were infected with intestinal Shigella, resulted in 59\% having no mucous within 5 days. After 5 days $96 \%$ had no fecal blood and significantly reduced number of stools/day [13]. These studies suggest green bananas could be included in the diet as an adjunct in the management of Shigellosis. Flavonoids and saponins present in green bananas might be responsible for the anti-diarrheal activity by inhibiting intestinal motility and hydro electrolytic secretion as well as inhibiting the release of histamines [14]. Green banana flour rich in resistant starches has protective effects during the intestinal inflammatory process. When rats with colitis were treated with green banana flour, they showed an improvement in the colonic oxidative status and anti-inflammatory

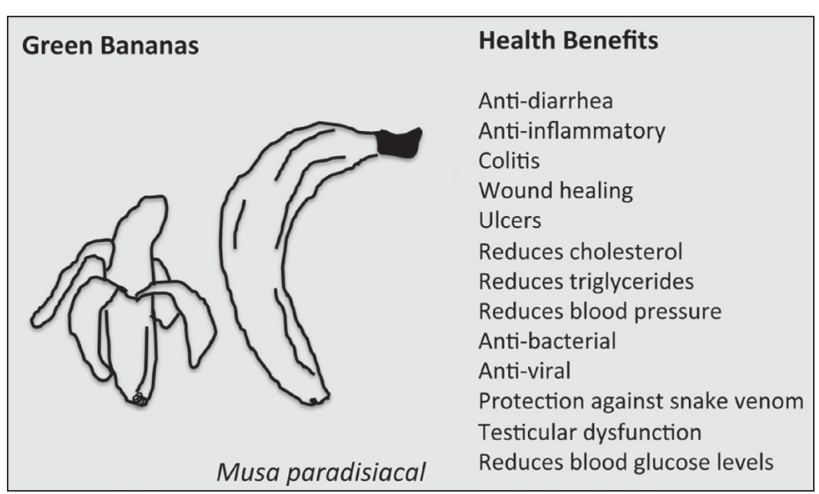

Figure 1. Summary of Green banana health benefits activity [15]. Methanolic extracts found in green bananas also promote better wound healing in rats $[16,17]$. Furthermore, a significant reduction of glutathione concentration in granulation tissues, percentage of wound area and increase in wound breaking strength [16] were observed in rats on a green banana diet. Green bananas are also reported to have potent anti-ulcer activity [18] which is attributed to the active ingredient flavonoid leucocyanidin [19]. Oral administration of green banana flour [20] or the natural flavonoid leucocyanidin isolated from green bananas, as well as synthetic leucocyanidin, all significantly increased the gastric mucus thickness in aspirin-induced gastric ulcer animals [21]. However, further studies are required to understand the mechanism of green bananas in anti-diarrhea, anti-inflammatory, anti-ulcer and wound healing processes.

Flavonoids present in green bananas have been shown to have hypolipidemic activity in rats [22] by significantly reducing cholesterol, phospholipids, free fatty acids and triglycerides in the serum, liver, kidney and brain of experimental animals. Higher rates of cholesterol degradation are also observed in rats through increased levels of hepatic, fecal bile acids and fecal neutral sterols [22]. Furthermore, consumption of green banana flour has also shown anti-atherosclerotic activity in rats $[23,24]$ and has been noted to reduce systolic blood pressure in humans [25].

There is evidence that lectins found in green bananas could provide a potential treatment for HIV patients and other viral infections such as, Ebola and hepatitis [26-28]. Other parts of the banana plant also have potential use in medical foods. For example banana leaf extracts from different species of Musa bananas have anti-bacterial activities, with Musa paradisiaca followed by Musa acuminata being the most active against multi-drug resistant nosocomial infection causing pathogens [29]. Musa paradisiaca species also demonstrates anti-bacterial activity against Pseudomonas aeruginosa and Staphylococcus aureus [17] and anti-coccidial activity in chickens [30]. In addition, banana peel extracts show anti-microbial activities against $P$. gingivalis and $A$. actinomycetemcomitans [31]. Interestingly, Musa paradisiaca may also offer some protection against snake venom toxicity [32]. Green bananas made into flour have been observed to provide beneficial effects in enhancing male semen counts at a low consumption dose $(500 \mathrm{mg} / \mathrm{kg} /$ day $)$, although at high doses $(1000 \mathrm{mg} / \mathrm{kg} /$ day $)$ significant lower sperm cell 
concentrations were noted [33]. Testicular dysfunction induced by diabetes, can result in high levels of oxidative stress released by testicular cells. Treatment of diabetic rats with Musa paradisiaca extract resulted in correction of testicular function [33]; however, further studies are required to validate the role of these extracts in the management of testicular disorders associated with diabetes. In other studies, the dietary fiber in Musa paradisiaca banana is reported to enhance the metabolism of carbohydrates in cholesterol free fed rats [34] and reduce blood sugar levels in diabetic induced rats [35]. In one human study, green banana flour consumption of $20 \mathrm{~g}$ /day by overweight female subjects for 45 days did not reduce body weight, however reductions in systolic blood pressure and fasting glucose levels were observed [25]. In another study, renal dysfunction in diabetic rats was significantly improved by the consumption of unripe Musa paradisiaca bananas but not when in combination with ginger [36]. Green banana flour has also been reported to have anti-cancer properties which should be further studied in the context for human dietary interventions [37].

\section{CONCLUSION}

In conclusion, there have now been sufficient studies to demonstrate that Green bananas appear to deliver an array of therapeutic benefits. However, the evidence to confirm support for particular medicinal or functional benefits is limited. In addition, certain benefits may be restricted to a specific species of banana. Further studies are therefore required to substantiate the benefits of specific banana species on disease outcomes and health, including their effects on immune cells as well as elucidating the mechanisms of actions.

\section{REFERENCES}

1 Suntharalingam S, Ravindran G. Physical and biochemical properties of green banana flour. Plant Foods Hum Nutr. 1993;43:19-27.

2 Faisant N, Gallant DJ, Bouchet B, Champ M. Banana starch breakdown in the human small intestine studied by electron microscopy. Eur J Clin Nutr. 1995;49:98-104.

3 Englberger L, Darnton-Hill I, Coyne T, Fitzgerald MH, Marks GC. Carotenoid-rich bananas: a potential food source for alleviating vitamin A deficiency. Food Nutr Bull. 2003;24:303-18.
4 Li S, Wu C, Nong H, Deng Y. [Morphometrical study on inhibitory effect of vitamin B6 and banana-stem extract on calcium crystallization]. Zhonghua Wai Ke Za Zhi. 1998;36:763-5.

5 Roth-Maier DA, Kettler SI, Kirchgessner M. Availability of vitamin B6 from different food sources. Int J Food Sci Nutr. 2002;53:171-9.

6 Zandonadi RP, Botelho RB, Gandolfi L, Ginani JS, Montenegro FM, Pratesi R. Green banana pasta: an alternative for gluten-free diets. J Acad Nutr Diet. 2012;112:1068-72.

7 Haslinda WH, Cheng LH, Chong LC, Noor Aziah AA. Chemical composition and physicochemical properties of green banana (Musa acuminata $\mathrm{x}$ balbisiana Colla cv. Awak) flour. Int J Food Sci Nutr. 2009;60 Suppl 4:232-9.

8 Prusky D. mechanisms of resistance of fruits and vegetables to postharvest diseses. Disease Resistance in Fruit, Proceedings of an international workshop. 1998:19-33.

9 Rabbani GH, Larson CP, Islam R, Saha UR, Kabir A. Green banana-supplemented diet in the home management of acute and prolonged diarrhoea in children: a community-based trial in rural Bangladesh. Trop Med Int Health. 2009;15:1132-9.

10 Rabbani GH, Teka T, Saha SK, Zaman B, Majid N, Khatun M, et al. Green banana and pectin improve small intestinal permeability and reduce fluid loss in Bangladeshi children with persistent diarrhea. Dig Dis Sci. 2004;49:475-84.

11 Rabbani GH, Teka T, Zaman B, Majid N, Khatun M, Fuchs GJ. Clinical studies in persistent diarrhea: dietary management with green banana or pectin in Bangladeshi children. Gastroenterology. 2001;121:554-60.

12 Triplehorn C, Millard PS. A rice-based diet with green banana or pectin reduced diarrhea in infants better than a rice-alone diet. ACP J Club. 2002;136:67.

13 Rabbani GH, Ahmed S, Hossain I, Islam R, Marni F, Akhtar M, et al. Green banana reduces clinical severity of childhood shigellosis: a double-blind, randomized, controlled clinical trial. Pediatr Infect Dis J. 2009;28:420-5.

14 Yakubu MT, Nurudeen QO, Salimon SS, Yakubu MO, Jimoh RO, Nafiu MO, et al. Antidiarrhoeal activity of Musa paradisiaca Sap in wistar rats. Evid Based Complement Alternat Med. 2015:Article ID, 683726. 
15 Scarminio V, Fruet AC, Witaicenis A, Rall VL, Di Stasi LC. Dietary intervention with green dwarf banana flour (Musa sp AAA) prevents intestinal inflammation in a trinitrobenzenesulfonic acid model of rat colitis. Nutr Res. 2012;32:202-9.

16 Agarwal PK, Singh A, Gaurav K, Goel S, Khanna HD, Goel RK. Evaluation of wound healing activity of extracts of plantain banana (Musa sapientum var. paradisiaca) in rats. Indian J Exp Biol. 2009;47:32-40.

17 Amutha K, Selvakumari U. Wound healing activity of methanolic stem extract of Musa paradisiaca Linn. (Banana) in Wistar albino rats. Int Wound J. 2014.

18 Vadivelan R, Elango K, Suresh B, Ramesh BR. Pharmacological validation of Musa paradisiaca Bhasma for antiulcer activity in albino rats - A preliminary study. Anc Sci Life. 2006;25:67-70.

19 Lewis DA, Fields WN, Shaw GP. A natural flavonoid present in unripe plantain banana pulp (Musa sapientum L. var. paradisiaca) protects the gastric mucosa from aspirin-induced erosions. J Ethnopharmacol. 1999;65:283-8.

20 Goel RK, Gupta S, Shankar R, Sanyal AK. Anti-ulcerogenic effect of banana powder (Musa sapientum var. paradisiaca) and its effect on mucosal resistance. J Ethnopharmacol. 1986;18:33-44.

21 Lewis DA, Shaw GP. A natural flavonoid and synthetic analogues protect the gastric mucosa from aspirin- induced erosions. J Nutr Biochem. 2001;12:95-100.

22 Vijayakumar S, Presannakumar G, Vijayalakshmi NR. Investigations on the effect of flavonoids from banana, Musa paradisiaca L. on lipid metabolism in rats. J Diet Suppl. 2009;6:111-23.

23 Usha V, Vijayammal PL, Kurup PA. Aortic/ glycosaminoglycans alterations in antiatherogenic action of dietary fiber from unripe banana (Musa paradisiaca). Indian J Med Res. 1991;94:143-6.

24 Verma V, Singh N, Jaggi AS. Sodium-hydrogen exchanger inhibitory potential of Malus domestica, Musa x paradisiaca, Daucus carota, and Symphytum officinale. J Basic Clin Physiol Pharmacol.25:99-108.

25 Tavares da Silva S, Araujo Dos Santos C, Marvila Girondoli Y, Mello de Azeredo L,
Fernando de Sousa Moraes L, Keila Viana Gomes Schitini J, et al. Women with metabolic syndrome improve antrophometric and biochemical parameters with green banana flour consumption. Nutr Hosp. 2014;29:107080.

26 Akkouh O, Ng TB, Singh SS, Yin C, Dan X, Chan YS, et al. Lectins with anti-HIV activity: a review. Molecules. 2015;20:648-68.

27 Singh SS, Devi SK, Ng TB. Banana lectin: a brief review. Molecules. 2015;19:18817-27.

28 Swanson MD, Winter HC, Goldstein IJ, Markovitz DM. A lectin isolated from bananas is a potent inhibitor of HIV replication. J Biol Chem. 2010;285:8646-55.

29 Karuppiah P, Mustaffa M. Antibacterial and antioxidant activities of Musa sp. leaf extracts against multidrug resistant clinical pathogens causing nosocomial infection. Asian Pac J Trop Biomed. 2013;3:737-42.

30 Anosa GN, Okoro OJ. Anticoccidial activity of the methanolic extract of Musa paradisiaca root in chickens. Trop Anim Health Prod. 2010;43:245-8.

31 Kapadia SP, Pudakalkatti PS, Shivanaikar S. Detection of antimicrobial activity of banana peel (Musa paradisiaca L.) on Porphyromonas gingivalis and Aggregatibacter actinomycetemcomitans: An in vitro study. Contemp Clin Dent. 2015;6:496-9.

32 Borges MH, Alves DL, Raslan DS, Pilo-Veloso D, Rodrigues VM, Homsi-Brandeburgo MI, et al. Neutralizing properties of Musa paradisiaca L. (Musaceae) juice on phospholipase A2, myotoxic, hemorrhagic and lethal activities of crotalidae venoms. J Ethnopharmacol. 2005;98:21-9.

33 Alabi AS, Omotoso GO, Enaibe BU, Akinola OB, Tagoe CN. Beneficial effects of low dose Musa paradisiaca on the semen quality of male Wistar rats. Niger Med J. 2013;54:92-5.

34 Usha V, Vijayammal PL, Kurup PA. Effect of dietary fiber from banana (Musa paradisiaca) on metabolism of carbohydrates in rats fed cholesterol free diet. Indian J Exp Biol. 1989;27:445-9.

35 Shodehinde SA, Ademiluyi AO, Oboh G, Akindahunsi AA. Contribution of Musa paradisiaca in the inhibition of alpha-amylase, alpha-glucosidase and Angiotensin-I converting enzyme in streptozotocin induced rats. Life Sci. 2015;133:8-14. 
36 Iroaganachi M, Eleazu C, Okafor P. Effect of Unripe Plantain (Musa paradisiaca) and Ginger (Zingiber officinale) on Renal Dysfunction in Streptozotocin-Induced Diabetic Rats. Jop. 2015;16:167-70.
37 Navarro SD, Mauro MO, Pesarini JR, Ogo FM, Oliveira RJ. Resistant starch: a functional food that prevents DNA damage and chemical carcinogenesis. Genet Mol Res. 2015;14:1679-91.

\section{ЗЕЛЕНИТЕ БАНАНИ И НИВНИТЕ ЗДРАВСТВЕНИ ПРИДОБИВКИ}

Васо Апостолопулос ${ }^{1}$, Јулијана Антонипилаи ${ }^{1}$, Кети Тангалакис ${ }^{1}, \bigsqcup_{\text {- }}$ Ф. Ештон ${ }^{2}$, Лили Стојановска ${ }^{1}$

${ }^{1}$ Центар за хронични болести, Школа за здравство и биомедицина, Универзитет Викторија, Ст Албанс Кампус, Мелбурн, Викторија, Австралија,

${ }^{2}$ Санаториум развој и иновации, Коранбонг, Нов Јужен Велс, Австралија

\section{Резиме}

Бананите имаат огромни здравствени придобивки како храна за животните и за луѓето. Тие се користат како комплементарна медицина за лекување на патолошки состојби уште од античките времиња. Од неодамна, има зголемен интерес за научната валидност на корисните ефекти на бананите во ублажувањето и лекувањето на заболувања, вклучувајќи ги чировите, инфекциите, дијабетесот, дијарејата, колитис и крвниот притисок. Овде, пишуваме за потенцијални терапевтски и функционални придобивки од одредени видови банани кога се консумираат зелени како и со оглед на својствата на екстрактите од неовошните делови на растението. Заклучивме дека зелени банани даваат низа здравствени и терапевтски придобивки.

Клучни зборови: банана, зелена банана, здравство, Musa paradisiacal, исхрана 